\title{
ANALYSES OF RADIATION OF ELECTROMAGNETIC WAVES IN THE HIGH-VOLTAGE AIR DUCT (150 kV) CONSTRUCTION ON HEALTH
}

\author{
Erwin Azizi Jayadipraja*
}

STIKES Mandala Waluya, Kendari, Indonesia

Accepted: 20 November 2017

*Correspondence:

Erwin Azizi Jayadipraja

STIKES Mandala Waluya, Kendari, Indonesia

E-mail : erwinazizijayadipraja@yahoo.com

Copyright: (C) the author(s), YCAB publisher and Public Health of Indonesia. This is an open-access article distributed under the terms of the Creative Commons Attribution Non-Commercial License, which permits unrestricted non-commercial use, distribution, and reproduction in any medium, provided the original work is properly cited.

\begin{abstract}
Background: High-voltage air ducts is the government program to supply electricity needs. However, in practice, obstacles have been identified in the form of rejection from the community due to the outstanding issues that high-voltage air ducts have an impact on health.

Aim: This research aims to analysis the magnitude of electromagnetic wave radiation of high-voltage air ducts construction on health.

Methods: The study was conducted by measuring electromagnetic wave radiation prior to high-voltage air ducts $(150 \mathrm{kV})$ construction and predicting the amount of radiation generated after this operation and its impact on health.

Result: The field measurement result showed that the highest strength of magnetic field in the absence of construction and operation activity of high-voltage air ducts $150 \mathrm{kV}$ was $0.00085 \mathrm{mT}$ and the highest electric field was $0.004241251 \mathrm{~V} / \mathrm{m}$. The results of the magnetic field strength analysis showed that the highest strength of magnetic field and electric field when the high-voltage air ducts is completed and operated was magnetic field of $0.00415 \mathrm{mT}$ and electric field of $38.4 \mathrm{~V} / \mathrm{m}$. The value was far lower than the standard limits recommended by IRPA / INIRC, WHO1990 and SNI 04-6950-2003. The allowed electric field strength is $5 \mathrm{kV} / \mathrm{m}$ and the allowed magnetic field strength is $0.1 \mathrm{mT}$.

Conclusion: Electromagnetic wave radiation of High-Voltage Air Ducts is not exceeded the allowed limit, so it will not cause a direct risk to health.
\end{abstract}

Key words: Transmission Line, Magnetic Field, Electric Field, Health

\section{INTRODUCTION}

National need for electrical energy experienced an average growth of $10.1 \%$ per year. The national electrical energy demand is estimated to increase to about 1,075 TWh by 2031, thus requiring additional national power to be approximately 237,020 MW by 2031 . In order to meet these demand, the government established a program of making 35,000 MW of power plants and 
transmission lines along 46,000 kilometers of circuits. ${ }^{1}$

The use of high-voltage air ducts transmission network has many advantages such as greater power supply and also power losses in transmission line can be suppressed. Besides the advantages, there are also disadvantages from the use of high-voltage air ducts, one of which is the magnetic field generated by the conductor, which is flowed by electric current. The high magnetic field has caused a lot of anxiety for human health, especially for those who live below or around the highvoltage airway transmission network. Until now, some communities are still worried about living under the Extra High Air Ducts.

Various public negative responses increased against the transmission line development plan, particularly its impact on health. Various studies have shown that high-voltage air ducts are assessed to be a health problem. High-voltage air ducts are assessed to be cancer-trigger ${ }^{2}$, can affect the amount of erythrocytes amounts and hemoglobin levels and cause polycythemia $^{3}$, affect the growth of animals $^{4}$ and plants ${ }^{5}$. In addition, highvoltage air ducts can be considered to worry the public with the phenomenon felt by people living below or around the highvoltage air ducts in the form of light arc, hiss sound, body hair-raising, or pen test and fluorescent lights up ${ }^{6}$. However, until now, no one can ensure that the health impacts mentioned are caused due to electromagnetic waves radiation. ${ }^{7-9}$

Today, there has been no health case reports that can be proven caused by radiation from electromagnetic waves of high-voltage air ducts. Government has set the safe distance for construction of highvoltage air ducts under Regulation of the Minister of Energy and Mineral Resources Number 18 of 2015 concerning the minimum free space and minimum safe distance on high-voltage air ducts, extra high voltage air ducts and high-voltage direct-current air ducts for power distribution. This paper aimed to show the magnetic field magnitude generated due to the construction of high-voltage air ducts with an analysis of the free space required for public health risks.

\section{METHODS}

A strong measurement of magnetic field and electric field strength was conducted before existence of high-voltage air ducts construction and operation activity. Magnetic field strength was measured using a Magnetic Field Meter (Teslameter or Gaussmeter). While the electric field strength was measured by Electrical Field Meter. Magnetic Field Meter produces output in Tesla or Gauss units. The Electric Field meter generates output in units of $\mathrm{V} / \mathrm{m}$.

Measurements were conducted at six points near the high-voltage air ducts which has activity or settlement nearby. Then the measurements were conducted at the conductor sag point between two towers. Measurements must be done by considering some parameters that might affect which is: measuring instrument position, measurement time, weather conditions, the conditions around the measurement point (open field, the presence of trees, the existence of the house etc.).

The magnitude of magnetic field depends on the shape of the current wire and can be calculated by the Biot-Savart law. Determining the value of the magnetic field in $\mathrm{x}$-component and $\mathrm{y}$-component is:

$$
\begin{aligned}
& H_{x}(x, y)=\frac{I_{c}}{2 \pi d} \sin (\theta)=I_{c} \cdot \frac{y-y_{c}}{2 \pi\left[\left(x-x_{c}\right)^{2}+\left(y-y_{c}\right)^{2}\right]} \\
& H_{y}(x, y)=\frac{I_{c}}{2 \pi d} \cos (\theta)=I_{c} \cdot \frac{x-x_{c}}{2 \pi\left[\left(x-x_{c}\right)^{2}+\left(y-y_{c}\right)^{2}\right]}
\end{aligned}
$$


The total magnetic field is:

$$
|H(x, y)|=\sqrt{\left|H_{x}(x, y)\right|^{2}+\left|H_{y}(x, y)\right|^{2}}
$$

The magnitude of the Electrostatics force of interaction between two point charges Q1 dan Q2 is directly proportional to the scalar multiplication of the magnitudes of charges and inversely proportional to the square of the distances between them.

In the transmission line, the electric potential $\mathrm{V}$ of the conductor is determined at a certain value. Therefore, the above equation in the previous discussion is used to obtain the charge density $\rho$ of each transmission line conductor. In this case, Equation (6) can be changed to:

$$
[\rho]_{\mathrm{n}}=2 \pi \epsilon_{0}[\mathrm{P}]_{\mathrm{nn}}{ }^{-1}[\mathrm{~V}]_{\mathrm{n}} \quad(\mathrm{C} / \mathrm{m})
$$

For conductor $\mathrm{i}$, the electric field strength towards point $\mathrm{P}$ can be written as follows:

$$
\overrightarrow{\mathrm{E}}_{\mathrm{pi}}=\frac{\rho_{\mathrm{i}}}{2 \pi e_{0}}\left[\frac{\left(\mathrm{x}_{\mathrm{p}-} \mathrm{x}_{\mathrm{i}}\right) \overrightarrow{\mathrm{a}}_{\mathrm{x}}+\left(\mathrm{y}_{\left.\mathrm{p}-\mathrm{y}_{\mathrm{i}}\right) \overrightarrow{\mathrm{a}}_{\mathrm{y}}}\right.}{\mathrm{r}_{\mathrm{i}}^{2}}\right]
$$

whereas for the shadow of conductor $i$, the electric field towards point $\mathrm{P}$ can be written as follows:

$$
\overrightarrow{\mathrm{E}}_{\mathrm{pii}}=\frac{\rho_{\mathrm{i}}}{2 \pi \epsilon_{0}}\left[\frac{-\left(\mathrm{x}_{\mathrm{p}}-\mathrm{x}_{\mathrm{i}}\right) \overrightarrow{\mathrm{a}}_{\mathrm{x}}-\left(\mathrm{y}_{\mathrm{p}}+\mathrm{y}_{\mathrm{i}}\right) \overrightarrow{\mathrm{a}}_{\mathrm{y}}}{\mathrm{r}_{\mathrm{ii}}^{2}}\right](\mathrm{V} / \mathrm{m})
$$

so that the total electric field strength at point $\mathrm{P}$, for the number of conductors $\mathrm{n}$, can be written as follows:

$$
\overrightarrow{\mathrm{E}}_{\mathrm{p}}=\sum_{\mathrm{i}=1}^{\mathrm{n}}[\overrightarrow{\mathrm{E}} \mathrm{pi}+\overrightarrow{\mathrm{E}} \mathrm{pii}](\mathrm{kV} / \mathrm{m})
$$

\section{RESULTS}

The measurement results at the study sites showed that the highest magnetic field strength before high-voltage air duct $150 \mathrm{kV}$ construction and operation was $0.00085 \mathrm{mT}$ and the highest electric field was $0.004241251 \mathrm{~V} / \mathrm{m}$.

The results of magnetic field strength analysis showed that the strongest magnetic field and electric field when the high voltage air duct was completed and operating were the highest magnetic field $0.00415 \mathrm{mT}$ and the highest electric field $38.4 \mathrm{~V} / \mathrm{m}$. This value was still far from the standard limits recommended by IRPA / INIRC, WHO1990 and SNI 04-6950-2003. The allowed electric field strength is 5 $\mathrm{kV} / \mathrm{m}$ and the allowed magnetic field is 0.1 $\mathrm{mT}$.

For more details, the value of electric field strength and magnetic field strength before and after the existing of high voltage air duct can be seen in table 1 and

\begin{tabular}{|c|c|c|}
\hline Classification & $\begin{array}{c}\text { Electric Field } \\
\left(\mathbf{k} V_{\mathrm{rms}} / \mathrm{m}\right)\end{array}$ & $\begin{array}{l}\text { Magnetic Fluctuations } \\
\text { Density }\left(\mathrm{mT}_{\mathrm{rms}}\right)\end{array}$ \\
\hline $\begin{array}{l}\text { Occupation: } \\
\text { 1. Whole work day } \\
\text { 2. Short Time } \\
\text { 3. Limbs } \\
\text { General environment : } \\
\text { 1. Up to } 24 \text { hours/day }{ }^{\text {c) }} \\
\text { 2. A few hours/day }\end{array}$ & $\begin{array}{l}10 \\
30^{\mathrm{a})} \\
- \\
5 \\
10\end{array}$ & $\begin{array}{l}0,5 \\
5^{\mathrm{b})} \\
25 \\
0.1 \\
1\end{array}$ \\
\hline
\end{tabular}
table 2, while for electric field and magnetic field distribution graph can be seen in Figure 1, 2, and 3.

Table 1. Recommendations for exposure limits to electric and magnetic fields 
Tabel 2. Electric field and Magnetic field strength before and after High-Voltage Air Duct construction

\begin{tabular}{|c|c|c|c|c|c|c|c|}
\hline No. & Tower & $\begin{array}{l}\text { Electric } \\
\text { Field } \\
\text { Strength } \\
(\mathbf{k V} / \mathbf{m})\end{array}$ & $\begin{array}{l}\text { Electric } \\
\text { Field } \\
\text { Strength in } \\
\text { operational } \\
(\text { a) } \\
(\mathrm{kV} / \mathrm{m})\end{array}$ & $\begin{array}{l}\text { Electric } \\
\text { Field } \\
\text { Strength in } \\
\text { operational } \\
\text { (b) } \\
(\mathrm{kV} / \mathrm{m})\end{array}$ & $\begin{array}{l}\text { Magnetic } \\
\text { field } \\
\text { strength } \\
(\mathrm{mT})\end{array}$ & $\begin{array}{l}\text { Magnetic } \\
\text { field } \\
\text { strength in } \\
\text { operational } \\
\text { (a) } \\
\text { (mT) }\end{array}$ & $\begin{array}{l}\text { Magnetic } \\
\text { field } \\
\text { strength in } \\
\text { operational } \\
\text { (b) } \\
\text { (mT) }\end{array}$ \\
\hline 1 & $\begin{array}{l}\text { TIP } 58 \text { and } \\
\text { TIP } 59\end{array}$ & $\begin{array}{c}0.00000409 \\
156\end{array}$ & 0.473 & 0.714 & 0.00082 & 0.00439 & 0.00727 \\
\hline 2 & $\begin{array}{l}\text { TIP } 181 \text { and } \\
\text { TIP } 182\end{array}$ & $\begin{array}{c}0.00000404 \\
1663\end{array}$ & 0.471 & 0.712 & 0.00081 & 0.00438 & 0.00726 \\
\hline 3 & $\begin{array}{l}\text { TIP } 208 \text { and } \\
\text { TIP } 209\end{array}$ & $\begin{array}{c}0.00000379 \\
2177\end{array}$ & 0.470 & 0.711 & 0.00076 & 0.00437 & 0.00725 \\
\hline 4 & $\begin{array}{l}\text { TIP } 278 \text { and } \\
\text { TIP } 279\end{array}$ & $\begin{array}{c}0.00000384 \\
2075\end{array}$ & 0.470 & 0.711 & 0.00077 & 0.00437 & 0.00725 \\
\hline 5 & $\begin{array}{l}\text { TIP } 362 \text { and } \\
\text { TIP } 363\end{array}$ & $\begin{array}{c}0.00000424 \\
1251\end{array}$ & 0.474 & 0.715 & 0.00085 & 0.00442 & 0.00728 \\
\hline 6 & $\begin{array}{l}\text { TIP } 411 \text { and } \\
\text { TIP } 412\end{array}$ & $\begin{array}{c}0.00000329 \\
3207\end{array}$ & 0.470 & 0.711 & 0.00066 & 0.00437 & 0.00725 \\
\hline
\end{tabular}

Notes:

$\mathrm{a}=$ With the existence of people working below the transmission sag of $150 \mathrm{kV}$

$\mathrm{b}=$ settlements/houses below the transmission sag of $150 \mathrm{kV} \mathrm{V}$

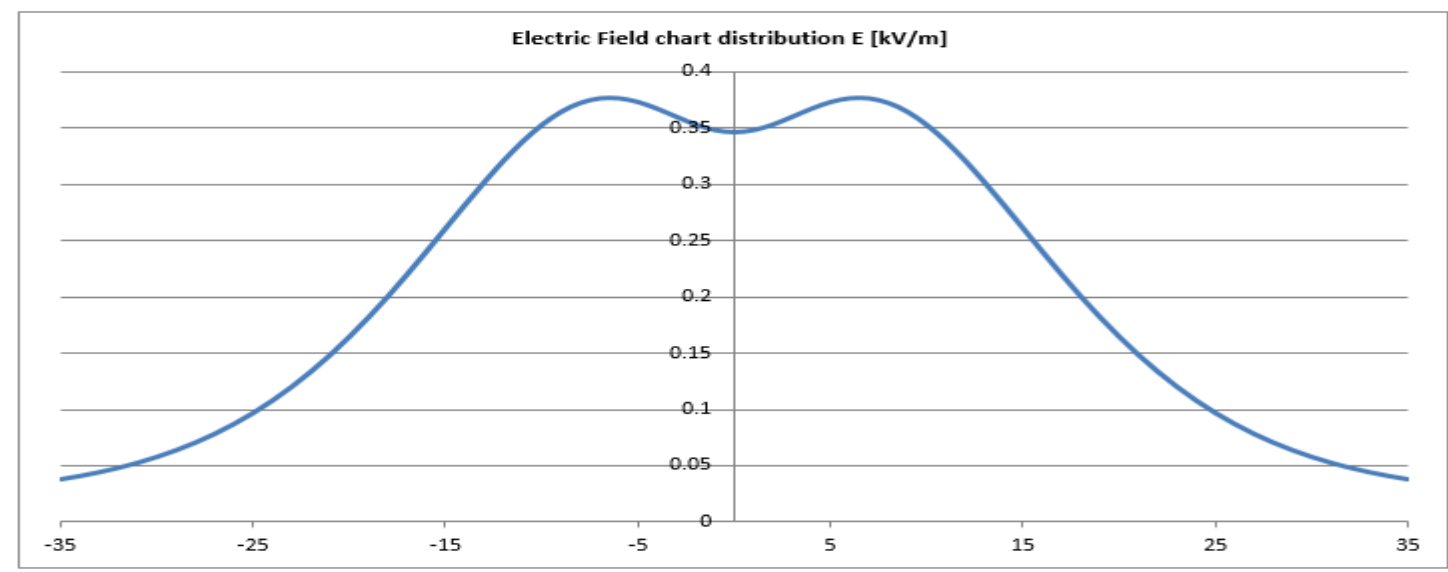

Figure 1. Electric field strength graph in 2D

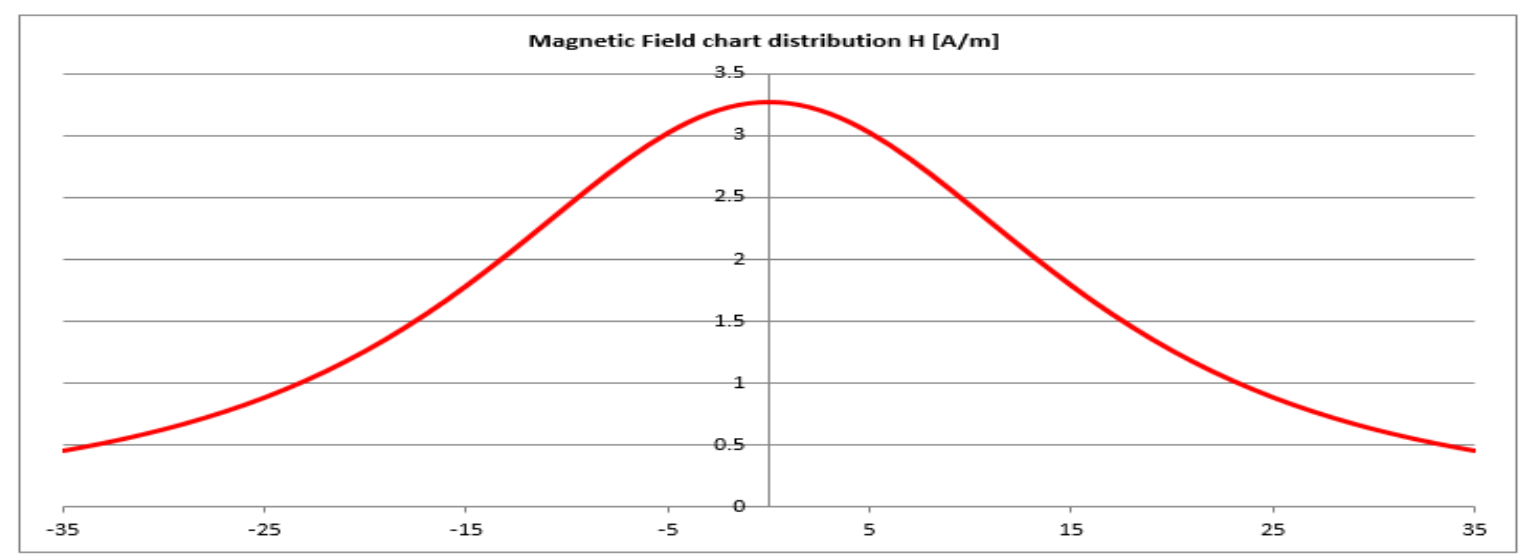

Figure 2. Magnetic field strength graph in 2D 


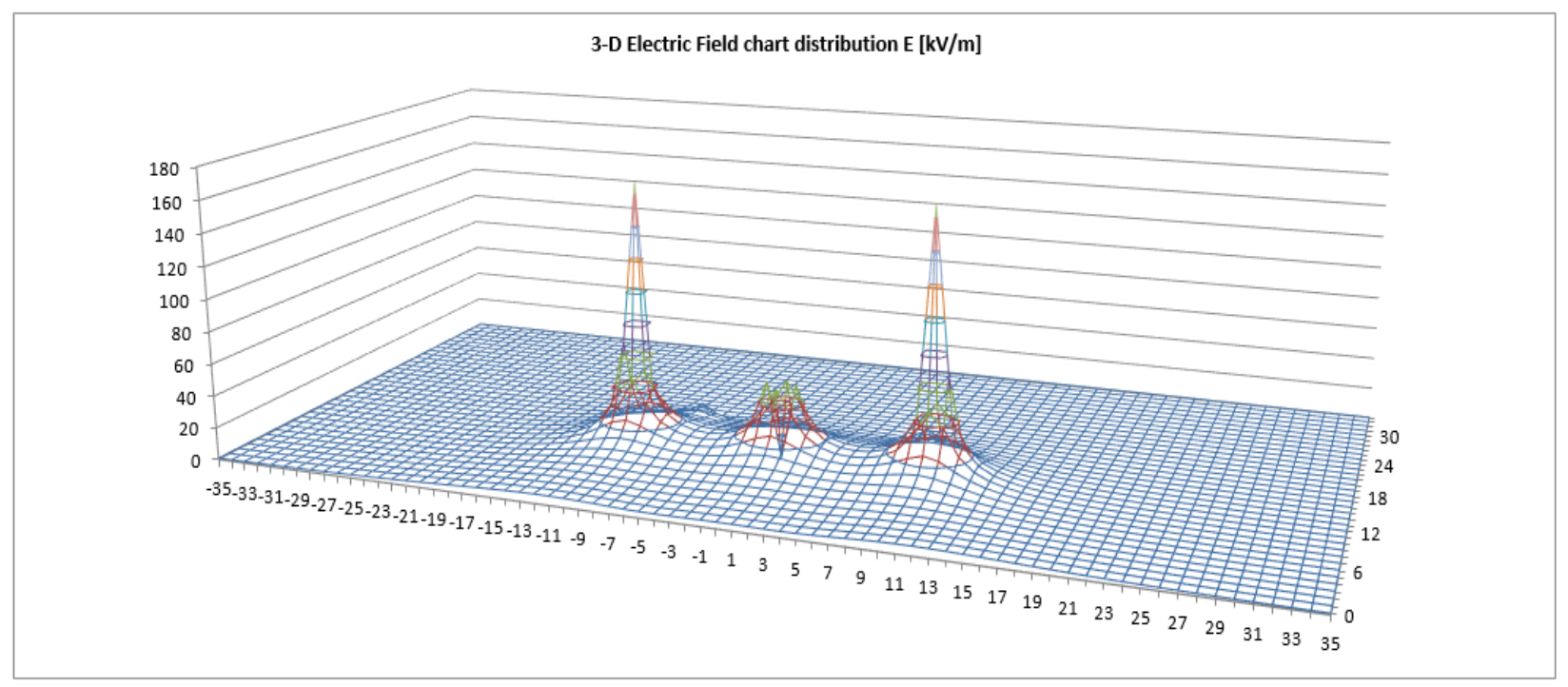

Figure 3. Electric field strength graph in 3D

\section{DISCUSSION}

Studies of the health effects caused by electromagnetic radiation have been extensively reviewed since $1950 .{ }^{10}$ Epidemiological studies were conducted in electromagnetic wave radiation effect on health, but it is needed to know that everyone receives radiation from various sources and places every day of his life. ${ }^{13}$ Health problems can occur due to the influence of heredity, nutrition, health care, behavior and environmental factors. ${ }^{14}$ So it is very difficult to determine whether the case of cancer that occurs in the community caused by the network line of high-voltage air duct. ${ }^{11,12}$ But until now the impact of electromagnetic wave radiation from this high voltage air duct to public health has not been certainly proven. ${ }^{13}$

Some studies that support it are anxiety disorders due to the presence of highvoltage air duct. Restlessness caused by the loud whirring noise of the cables comes in the rain season. This disturbance of tranquility or restlessness can cause psychological pressure that trigger stress, which ultimately will disrupt the activities of social citizens. ${ }^{6,14,15}$ In addition, the high-voltage air ducts building can also disrupt property values in the neighborhood. ${ }^{16}$

The presence of electric fields and magnetic fields around human life cannot be perceived by the human senses, unless the intensity is large enough and felt only by the hypersensitive person. Electrical fields and magnetic fields from high voltage air ducts include non-ionizing radiation groups. This radiation is relatively harmless, completely different from ionizing radiation such as nuclear radiation or X-ray radiation. Both electric field and magnetic field had actually existed since the earth was formed. In clouds containing potential water, there is an electric field that is between 3000$30,000 \mathrm{~V} / \mathrm{m}$. Likewise, the earth naturally has an electric field $(100-500 \mathrm{~V} / \mathrm{m})$ and a magnetic field $(0.004-0.007 \mathrm{mT})$. An installation system which has voltage and current always generates an electric field. But this electric field has been weakened because the distance is quite far from the source.

The value of electromagnetic wave radiation in construction plan track of high-voltage air ducts is following the Regulation of Minister of Energy and 
Mineral Resources No. 18 of 2015 about minimum free space and safe distance from high voltage air ducts, extra high voltage air ducts and direct-current high- voltage air ducts for power supply (Table 3 and Figure 4) are still very far from the standard limit.

Table 3. Vertical Minimum Free Distance from Conductor (cable)

\begin{tabular}{|c|c|}
\hline Location & $\begin{array}{l}\text { Free Space from } 150 \\
\text { kV (m) }\end{array}$ \\
\hline Open field or open area ${ }^{a}$ & 8.5 \\
\hline \multicolumn{2}{|l|}{ The areas with the certain conditions } \\
\hline Building, bridge ${ }^{b)}$ & 5.0 \\
\hline Plants, forest and vegetation ${ }^{b}$ & 5.0 \\
\hline Road/Highway, Railway ${ }^{\text {a) }}$ & 9.0 \\
\hline Public Field ${ }^{\text {a) }}$ & 13.5 \\
\hline Another SUTT, SUTR, SUTM & 4.0 \\
\hline The highest point of the ship pole at the highest tide & 4.0 \\
\hline
\end{tabular}

Source: Regulation of Minister of Energy and Mineral Resources No. 18 of 2015

Notes:

${ }^{a}=$ The vertical minimum free distance that calculated from the surface of the earth or road surface/rail

${ }^{b}=$ The vertical minimum free distance that calculated from the conductor to the nearest highest point
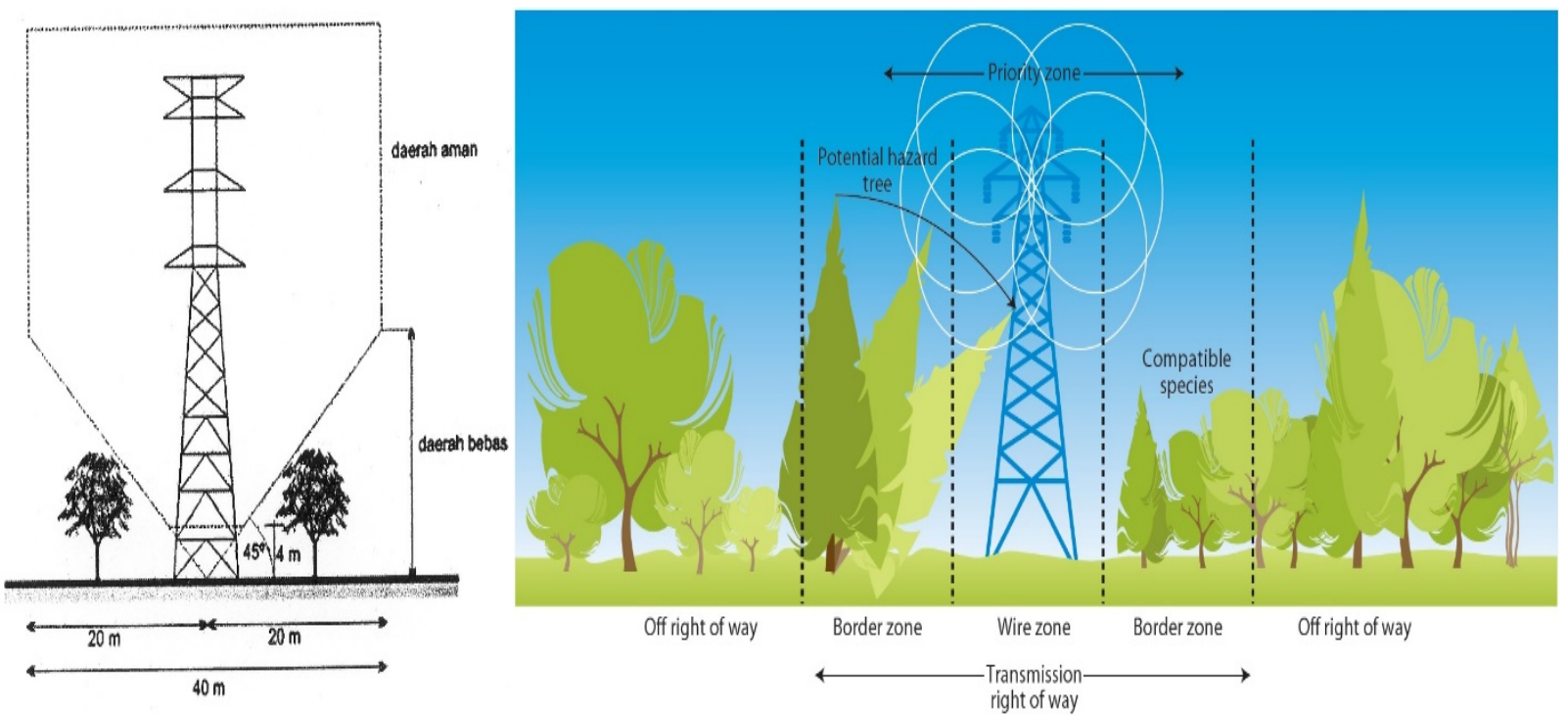

Figure 4. Cross-section of Free Space

The terms of free space and safe space also known in construction of high-voltage air ducts. Free space is a space that must be free of objects and other activities. The free space is set to be differently in size and shape. While safe space is a space outside free space where in this safe space, its land or soils can still be utilized. The effect of electric field and magnetic field strength in the safe space has been considered using reference to valid regulations. The free space and the safe space can be adjusted as needed when preparing the structure design.

Theoretically, if the exposure exceeds the established standard limit, it can cause problems in the blood system (leukemia and lymphoma), reproduction (male infertility, congenital defects, impotence), nervous system (degenerative), cardiovascular system (rhythm change, metabolism changes), endocrine 
systems/others (melatonin, bone growth, skin changes $)^{10} 17$.

Reducing electromagnetic radiation can be done by adjusting the distance of the sag/network cable according to specified free space safe limits, placing the grounding wire between pasha conductor and ground surface contour ${ }^{18}$, conducting an environment-based management to community living below and around highvoltage air duct ${ }^{6}$. Installing a house roof or plafond and planting certain types of plants are inefficient and will not have any significant effect on the reduction of electromagnetic waves radiation. ${ }^{19} 20$

\section{CONCLUSION}

The electromagnetic wave radiation of high-voltage air ducts was built in accordance with the Regulation of the Minister of Energy and Mineral Resources No. 18 of 2015 that was not exceeded the standard limit permitted by IRPA / INIRC, WHO1990 and SNI 04-6950-2003, so it will not cause a direct risk to health.

\section{ACKNOWLEDGMENT}

The authors would like to thank Mr. Abdul Haris Djalante, Mr. Ahmad Alifathur Rusvan and Miss Hildayani for their assistance to the researcher in facilitating the measuring tools and analyzing the results obtained so that the research can be completed. The authors also would like to thank all the persons who have helped a lot that cannot be mentioned one by one.

\section{REFERENCES}

1. Amien I, Runtunuwu E. Capturing the benefit of monsoonal and tropical climate to enhance national food security. Jurnal Penelitian dan Pengembangan Pertanian. 2016; 29(1).

2. Henshaw D. Does our electricity distribution system pose a serious risk to public health? Medical Hypotheses. 2002;59(1):39-51.

3. Nuryanti A. Pengaruh Radiasi Simulasi Saluran Udara Tegangan EkstraTinggi (SUTET) Terhadap Jumlah Eritrosit Dan Kadar Hemoglobin Sprague Dawley. Majalah Kedokteran Gigi. 2007; 14(2007).

4. Kuaumawati I, Anne Handrini Dewi R. Pengaruh Lama Radiasi Alat Simulasi saluran Udara Tegangan Ekstra Tinggi (SUTET) Terhadap Panjang Lingkar Kepala Anak Tikus Sprague Dawley. Majalah Ilmu Kedokteran Gigi. 2008;10(2008).

5. Sri Budarsa I, Sandi Adnyana I, Mahardika IG. STUDI PAPARAN MEDAN MAGNET SALURAN UDARA TEGANGAN EKSTRA TINGGI (SUTET) PADA PERTUMBUHAN SAYURAN CAISIM (BRASSICA JUNCEA L). Ecotrophic: Journal of Environmental Science. 2009;4(2).

6. Anies A. Mengatasi Gangguan Kesehatan Masyarakat Akibat Radiasi Elektromagnetik Dengan Manajemen Berbasis Lingkungan. 2007.

7. Swamardika IBA. Pengaruh radiasi gelombang elektromagnetik terhadap kesehatan manusia. Majalah Ilmiah Teknologi Elektro. 2009;8(1).

8. Kurniawan B, Wahyuni I. Hubungan Radiasi Gelombang Elektromagnetik Dan Faktor Lain Dengan Keluhan Subyektif Pada Tenaga Kerja Industri Eletronik GE di Yogyakarta. Jurnal Promosi Kesehatan Indonesia. 2008; 3(2):127-133.

9. Suhartono S. KASUS SUTET DI INDONESIA: KAJIAN DARI ASPEK EPIDEMIOLOGI. Buletin Penelitian Kesehatan. 2008;36(4 Des).

10. Riyadina W. EFEK BIOLOGIS DARI PAPARAN RADIASI ELEKTROMAGNETIK. Media Penelitian dan 
Pengembangan Kesehatan. 1997;7(01 Mar).

11. Ahlbom I, Cardis E, Green A, et al. Review of the epidemiologic literature on EMF and health. Environmental health perspectives. 2001;109(Suppl 6):911.

12. Jayadipraja EA, Daud A, Assegaf AH. Air Pollution and Lung Capacity of People Living around the Cement Industry. Public Health of Indonesia. 2016;2(2):76-83.

13. Alatas Z, Lusiyanti Y. Efek kesehatan radiasi non pengion pada manusia. Cermin Dunia Kedokteran. 2003; 138:34-40.

14. Arbi M. Identifikasi Prilaku Dan Kondisi Sosial Ekonomi Masyarakat Yang Bermukim Di Sekirar Jaringan Sutt Transmisi Palembang, Sumatera Selatan. Jurnal Agripita. 2012; 1(4):233-242.

15. Kurniawan IA, Amrita A. STUDI INTENSITAS MEDAN LISTRIK SUTT 150 KV KONFIGURASI HORIZONTAL UNTUK LINGKUNGAN PEMUKIMAN. Jurnal Ilmiah SPEKTRUM.2(4):32-38.

16. Priestley T, Evans GW. Resident perceptions of a nearby electric transmission line. Journal of Environmental Psychology. 1996; 16(1):65-74.
17. Portier CJ, Wolfe MS. Assessment of health effects from exposure to powerline frequency electric and magnetic fields. NIH publication. 1998;98:3981.

18. Utama B. PENGURANGAN POLLUSI RADIASI MEDAN ELEKTROMAGNETIK DENGAN PENEMPATAN KAWAT GROUNDING ANTARA KONDUKTOR PHASA DAN KONTUR PERMUKAAN TANAH. Paper presented at: Prosiding Seminar Nasional ReTII2015.

19. Yulia E. PENGARUH JENIS ATAP RUMAH TERHADAP PENURUNAN INTENSITAS MEDAN MAGNET DI BAWAH SUTT 150 KV. JURNAL PEMBELAJARAN FISIKA. 2017;6(1):83-91.

20. Hadi AI, Samdara R, Nurliana H. Efisiensi tumbuhan dalam meredam Gelombang elektromagnetik (studi kasus di sutt kota bengkulu). GRADIEN. 2012;8(1):722-727.

Cite this article as: Jayadipraja EA. Analyses of Radiation of Electromagnetic Waves in the HighVoltage Air Duct $(150 \mathrm{kV})$ Construction on Health. Public Health of Indonesia 2017; 3(4):152-159 